"sacrifice," offered to the "power" of the doctor to heal (a kind of magical thinking to keep misfortune away). ${ }^{4}$

The sociological critique is not as materialistic as first seems; this is just as well. For the reduction of gift giving to instrumental exchange can obscure important messages: the man relapsing into mania may bring an extravagant gift; the elderly widow, dying, might say "goodbye" with one,${ }^{19}$ as might the suicidal patient ${ }^{1}$; the erotomanic patient might send their doctor a single theatre ticket, ${ }^{20}$ and the disgruntled patient may give their doctor a medical textbook. The wealth of meaning surrounding the gift may repay reflection.

\section{What is to be done?}

The most appropriate advice is to take nothing for granted and reflect upon the gift and its timing. A polite refusal may be preceded by reference to the ethics of medical practice or could emphasise that declining a gift does not equate to rejecting the patient. Whatever the outcome, a thank you note is appropriate. ${ }^{4}$ Keeping a record of all gifts offered or received and discussing the matter openly with colleagues promotes transparency.

\section{The intangible}

Finally, doctors and their colleagues receive other "gifts" from patients all the time, ${ }^{21}$ without the donors' awareness, such as the vicarious satisfaction the doctor derives from their patients' recovery or the deep impression they leave behind when showing great courage in the face of suffering-as with the elderly man who walked in retention through snow, on Christmas Eve, until he reached the emergency department.

Competing interests: None declared.

1 Stein H. The gift in therapy. Am J Psychother 1965;19:480-8.

2 Lyckholm LJ. Should physicians accept gifts from patients? JAMA 1998; 280:1944-6.

Capozzi JD, Rhodes R. Gifts from patients. J Bone Joint Surg Am 2004; 86A:2339-40.

4 Drew J, Stoeckle JD, Billings JA. Tips, status and sacrifice: gift giving in the doctor-patient relationship. Soc Sci Med 1983;17:399-404.

5 Smolar AI. Reflections on gifts in the therapeutic setting: the gift from patient to therapist. Am J Psychother 2002;56:27-45.

6 Levene MI, Sireling L. Gift giving to hospital doctors-in the mouth of Levene MI, Sireling L. Gift giving to
the gift horse. BMJ 1980;281:1685.

7 Hundert EM. Looking a gift horse in the mouth: the ethics of gift-giving in psychiatry. Harv Rev Psychiatry 1998;6:114-7.

8 Nisselle P. Danger zone-when boundaries are crossed in the doctor-patient relationship. Aust Fam Physician 2000;29:541-4.

9 Cheung ST. The effects of chocolates given by patients on the well-being of nurses and their support staff. Nutr Health 2003;17:65-9.

10 Rycroft C. A critical dictionary of psychoanalysis. London: Penguin, 1972:100 (first published 1968).

11 Ingvar DH. 'Memory of the future': an essay on the temporal organization of conscious awareness. Hum Neurobiol 1985;4:127-36.

12 Oxford English dictionary. Oxford: Oxford University Press, 2005.

13 Andereck W. Point-counterpoint: should physicians accept gifts from their patients? Yes: if they are given out of beneficence or appreciation. West J Med 2001;175:76.

14 Weijer C. Point-counterpoint: should physicians accept gifts from their patients? No: gifts debase the true value of care. West J Med 2001;175:77.

15 Nadelson C, Notman MT. Boundaries in the doctor-patient relationship. Theoretical Medicine 2002;23:191-201.

16 Main TF. The ailment BrJ Med Psychol 1957:30:129-45.

17 General Medical Council. Good medical practice. London: GMC, 2001:17. Committee on Bioethics. Appropriate boundaries in paediatrician-
family-patient relationship. Paediatrics 1999;104:334-6.

19 Kellehear A, Lewin T. Farewells by the dying: a sociological study. Omega 1988-1989;19:275-92.

20 Berrios GE, Kennedy N. Erotomania: a conceptual history. History of Psychiatry 2002;13:381-400.

21 Kline NE. Gifts from children.J Paediatr Oncol Nursing 2002;19:1.

(Accepted 4 October 2005)

\title{
Physician, know thyself
}

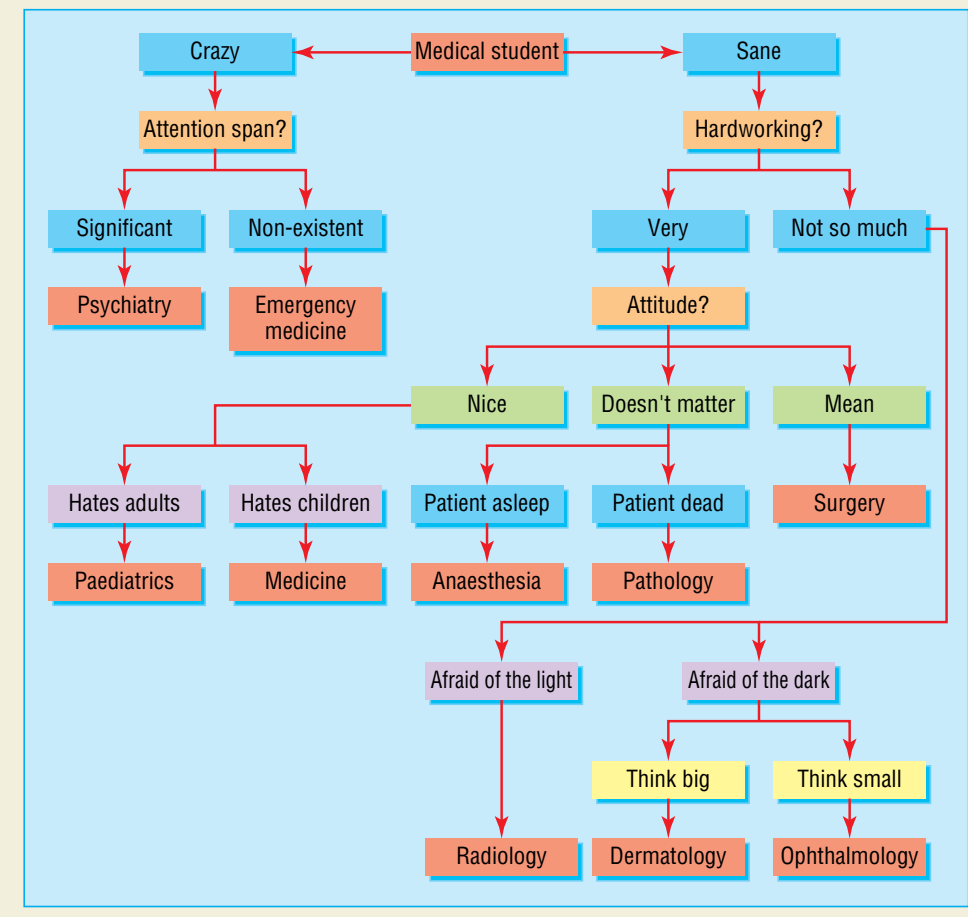

As a resident physician working in a large academic medical centre, I am in frequent contact with medical students, many of whom feel apprehensive about choosing their future medical specialty. Students complain that they need balanced career guidance extending beyond "my specialty is the best" expressed by many doctors. Inspired by my interactions with residents training in all major specialties, I have created an algorithm to guide students' choice of specialty on the basis of their personality characteristics. The algorithm has been well received at my institution by students and residents alike, many of whom exclaim: "That is so true."

I provide the algorithm in the hope that it will be equally useful to the journal's readers.

Boris Veysman resident, Yale School of Medicine, New York University, New York, USA (boris.veysman@med.nyu.edu) 